\title{
RESENHA
}

\section{Desafios brasileiros na era dos gigantes*}

VIRGÍLIO ARRAES*

Nos últimos anos, intensificaram-se os debates nos meios de comunicação e na academia sobre a política externa brasileira, em decorrência do êxito eleitoral da oposição no âmbito federal em 2002, após três pleitos disputados (89, 94 e 98). Deste modo, o cotejo entre o desempenho das gestôes de Fernando Henrique Cardoso e de Luis Inácio Lula da Silva foi constante, ainda mais durante as vésperas da última eleição presidencial (2006), de cujo resultado se extrairia a confirmação do atual titular.

Em face da proximidade das políticas econômicas executadas no último decênio, a política externa tornar-se-ia para muitos o cenáculo em que situação e oposição - manifesta não apenas nos meios partidários - se avaliariam, por ela eventualmente possibilitar a diferença das linhas traçadas, posterior execução e, por fim, auferimento dos êxitos.

No entanto, exame mais pormenorizado permite vislumbrar que a diferenciação almejada não é tão significativa do ponto de vista estrutural, em decorrência da primazia excessiva do Ministério da Fazenda dentro do Poder Executivo. Nesse sentido, há um aperfeiçoamento da capacidade na área comercial, materializado por índices mais robustos e articulaçōes políticas mais presentes, conforme apontou, por exemplo, a formulação do G-20 em 2003, direcionado para as negociações na Organização Mundial do Comércio (OMC).

$\mathrm{O}$ não resumir-se a questôes econômicas é o mérito maior do livro de Guimarães, atual secretário-geral do Ministério das Relações Exteriores, onde uma dúzia de ensaios enfeixa-se de modo alentado. Temas considerados secundários pelo cânone intelectual formulado no fim da Guerra Fria, na transição da década de 1980 para a de 1990, são recuperados e analisados naturalmente sob o ideário contemporâneo vigente, porém a partir de uma perspectiva local, sem incorrer em tinturas de saudosismo ou de nacionalismo de caráter autoritário.

\footnotetext{
* Resenha de GUIMARÃES, Samuel Pinheiro. Desafios brasileiros na era dos gigantes. Rio de Janeiro: Contraponto, 2006, 455 p., ISBN:85-85910-79- 8.

** Professor do Instituto de Relações Internacionais da Universidade de Brasília - UnB (arraes@unb.br).
} 
Portanto, questóes, como a do posicionamento do Estado perante a sociedade, a fim de induzir o desenvolvimento de modo menos irregular socialmente; do papel da cultura nacional dentro das formulações políticas e econômicas, com o objetivo de adaptar o país à contemporaneidade sem desaguar, contudo, no mimetismo, de tão temerárias implicações no cotidiano de uma população; do conhecimento mais amplo das implicações decorrentes da vastidão territorial, principalmente da Amazônia, com o propósito de aproveitar melhor o potencial das capacidades e riquezas; ou da atribuição hodierna das forças armadas e da tecnologia militar, voltadas não somente para as fronteiras, mas edificadas em virtude de tópicos globais, como terrorismo, são tratadas com diligência.

Em um momento em que a influência do neoliberalismo periférico ainda subsiste no continente sul-americano - não obstante a perda do entusiasmo por grande parte do eleitorado, ao observar a manutenção do hiato sócioeconômico, mesmo após inúmeras alterações significativas na estrutura econômica - faz-se mister o refletir não apenas sobre os depauperados resultados da aplicação intensa do ideário emergido dos grandes centros de poder como sobre as possíveis alternativas a serem implementadas, de sorte que o Brasil retome e consolide o processo de desenvolvimento.

Como derivação de tal necessidade, Guimarães examina as possibilidades do Brasil com base em uma perspectiva em que o Estado democratizado farse-ia mais e mais presente, indo de encontro à ortodoxia ainda em vigor, mesmo que aparentemente minimizada, vinculada à concepção progressivamente mercantilista das relações sociais como modo de encaminhar e superar diferenças e desavenças internas.

Ao ter por base a atuação das elites dos países centrais, o autor registra uma movimentação na redistribuição de poder, distinta da apregoada na década passada que rumaria supostamente para menor desequilíbrio global por meio da atuação desembaraçada do mercado. Passado o primeiro momento, de efêmero deslocamento de investimentos externos para o antigo Terceiro Mundo, com o intuito de participar das privatizações, as tensões econômicas recrudesceram por meio do dissenso emanado de organismos internacionais como a OMC ou Fundo Monetário Internacional (FMI).

Por meio da renovação tecnológica, em muitos casos, individual e da normatização econômica e militar multilateral, grandes potências reiteram o status quo, amparados na visão tradicional de poder, por vezes, tão-somente remodelada. Por sua vez, isto obriga países periféricos a redesenhar sua inserção em um ambiente em que o ceticismo substitui o otimismo, fruto da utopia liberal do encerramento da divergência bipolar.

Restaria ao Brasil, sem desvalorizar os fóruns multilaterais, alinhavar suas opções. Uma delas, em função de seu perfil geopolítico, se estenderia à Argentina e, conseqüentemente, ao Mercosul, enquanto a outra se aplicaria aos Estados 
Unidos. Com estes, a definição de um relacionamento consciente das disparidades de poderio, porém sem subordinação; com aquela, o estabelecimento de relação em que haja a conformação de uma visão de mundo próxima, proporcionadora de inserção mais altiva no cenário internacional.

Obra de síntese, acalentada na conjugação de fundamentada experiência intelectual com larga vivência profissional do autor, ela expõe a distância em que se encontra o Brasil, apesar do posfácio favorável ao momento de hoje, de um projeto realmente transformador, que facultasse a transição para uma sociedade mais bem constituída socialmente e, por conseguinte, mais desenvolta e confiante em seu desempenho internacional. 